УДК 340.1; 342.55

\author{
Ніна Анатолї̈вна Мяловицька, \\ доктор юридичних наук, професор, професор кафедри \\ конституиійного права юридичного факультету \\ Київського національного університету \\ імені Тараса Шевченка
}

Ніна Едуардівна Златіна, кандидат юридичних наук, дочент кафедри права факультету економіки і права Київського національного лінгвістичного університету

\title{
ДОГОВІР ЯК ДЖЕРЕЛО ПРАВА
}

Постановка проблеми. Розвиток права - складний, багатоетапний процес. 3 виникненням різних підходів до розуміння права формувалось та змінювалось розуміння про його джерела. Дискусія щодо змісту цього поняття триває і в сучасний період. Автори, які надають перевагу позитивістському підходу, під джерелами права розуміють спосіб зовнішнього вираження змісту правових норм, за допомогою якого вони набувають загальнообов'язкового значення. У цьому контексті джерела права ототожнюються із нормативними приписами, що приймаються або санкціонуються державою. Для представників природно-правової доктрини джерелами права $є$ природні, невідчужувані права людини, а прихильники соціологічної юриспруденції джерелом права визнають типізовані взаємовідносини між суспільними союзами, які передують появі правової норми [1, с. 152].

Незважаючи на багатоманітність підходів до визначення поняття «джерела права», підтримуємо позицію вчених-правознавців, які розуміють під «джерелом права» - спосіб зовнішнього вияву правових норм, який засвідчує їх загальнообов'язковість [2, с. 17].

До основних видів джерел права відносяться нормативно-правові акти, судові прецеденти, правові звичаї, нормативні договори та ін. Одним з актуальних питань, що привертають сьогодні увагу правознавців, $\epsilon$ аналіз договорів, що стали джерелами права в XX-XXI ст.

Аналіз останніх досліджень і публікацій. Вагомий внесок у наукову розробку поняття та класифікації джерел права зробили такі українські вчені, як П. Ентін, М. Кельман, М. Козюбра, В. Копійка, М. Марченко, В. Муравйов, О. Мурашин, Н. Оніщенко, Н. Пархоменко, П. Рабінович, Ю. Тихомиров, В. Шаповал, Ю. Шемшученко та ін.

Однак сучасні реалії суспільного розвитку, зокрема, поступової євроінтеграції України, потребують нових підходів до їх аналізу та узагальнень.

Метою статті $\epsilon$ аналіз договорів, що стали джерелами права у федеративних і унітарних державах світу, а також у міждержавному утворенні конфедеративному типу - Свропейському Союзі (СС).

Основні результати дослідження. В юридичній літературі $\epsilon$ різні точки зору на визначення поняття «договір». Не вдаючись до докладного аналізу різних точок зору з цього питання, пропонуємо інтегроване визначення цього поняття в наступній редакції. Договір як джерело права визначається як об'єктивоване, формально обов'язкове правило поведінки загального характеру, встановлене за взаємною домовленістю держав, державних утворень, їх органів державної влади у питаннях їх взаємовідносин. Існує три основних види таких договорів:

1. Договори, які укладаються незалежними державами про утворення нової федеративної держави. Як правило, ці договори визначають зміст конституції федеративної держави. Саме таким був Договір про утворення СРСР, який був підписаний Росією, Україною, Білорусією і Закавказькою Федеративною Республікою 30 грудня 1922 року і після обговорення на місцях та доопрацювання включений до Конституції СРСР 1924 року [3]. Слід відзначити, що дві інші федеративні соціалістичні держави - Югославія і Чехословаччина були створені не на договірних засадах. Однак поділ Чехословаччини на Чехію і Словаччину з 1 січня 1993 року відбувся згідно з договором. Прикладом договору цього виду можуть служити також статті про союз між Республікою Танганьїка і Народною Республікою Занзібар і Пемба від 26 квітня 1964 року, які лягли в основу конституції 
Об'єднаної Республіки Танзанія 1965 року [4], договір про об'єднання ФРН і НДР від 31 серпня 1990 року, положення якого закріплені в ст. 20 Конституції Німеччини 1949 року [5, с. 396] та ін.

2. Внутрішньодержавні договори укладаються головним чином, у федеративних державах. Ïх предметом найчастіше $є$ правовий статус суб'єктів федерацій та автономних утворень, зокрема питання про розмежування компетенції між федерацією та її суб'єктами, про взаємовідносини між самими суб' єктами федерації тощо. Однак внутрішньодержавні договори стають джерелами права лише в тому разі, коли суб'єкти їх укладення мають на це відповідні конституційні повноваження.

Такі повноваження передбачені, наприклад, у конституції Німеччини.

Так, ст. 29 Основного закону ФРН встановлює, що зміни у статусі земель (за винятком їхніх кордонів) «можуть здійснюватися шляхом державних договорів між зацікавленими землями або шляхом прийняття федерального закону за згодою Бундесрату, якщо на території, чия приналежність до землі має змінитися, проживає не більше 10 тисяч жителів. Подробиці регулюються федеральним законом, котрий потребує згоди Бундесрату та більшості членів Бундестагу. Він має передбачати заслуховування думки зацікавлених громад і округів» [6, с. 167].

Крім федеративних держав, внутрішньодержавні договори існують у деяких унітарних державах.

Так, відповідно до п. 2 ст.145 Конституції Іспанії 1978 р. у статутах автономних співтовариств можуть бути передбачені «умови і порядок, при дотриманні яких автономні співтовариства можуть укладати між собою договори для управління і надання допомоги їх власним службам, про характер і мету яких будуть повідомлені Генеральні Кортеси. В інших випадках договори про співробітництво між автономними співтовариствами укладаються лише з дозволу Генеральних Кортесів» [6, с. 337].

Конституція Республіки Узбекистан передбачає, що взаємовідносини між органами державної влади цієї країни та органами державної влади політичної автономії, що входить до ії складу - Республіки Каракалпакстан регулюються договорами та угодами, які укладаються між ними в рамках Узбецької Конституції. Спірні питання вирішуються шляхом узгоджувальних процедур.

Слід згадати і про Республіку Боснія і Герцеговина, Конституція якої була затверджена на договірних засадах органами державної влади Республіки та ії автономних складових частин на мирній конференції у Парижі 14 грудня 1995 р. [7, с. 265].

Прикладом внутрішньодержавного договору в унітарній державі може служити також Конституційний договір між Президентом України та Верховною Радою України від 8 червня 1995 p. «Про основні засади організації та функціонування державної влади і місцевого самоврядування в Україні на період до прийняття нової Конституції України» [8].

3. Нові тенденції в розвитку світового співтовариства після Другої світової війни, зокрема, демократизація суспільного життя, посилення інтеграційних процесів, глобальний характер міграції, вироблення міжнародних стандартів прав людини та їх міжнародного захисту, спричинили виникнення нового виду джерел права - міжнародно-правових актів та актів наддержавних організацій. Ці акти мають пряму дію на державній території, тобто є джерелами права, що визнається дедалі зростаючим числом сучасних держав світу.

Слід зазначити, що у другій половині ХХ ст. помітно посилився процес відродження та поширення конфедеративних ідей і принципів. Насамперед збільшується кількість конфедеративних утворень, тобто з'являються їх нові форми і види. Прикладом конфедеративного об'єднання під назвою Європейський Союз (СС) було утворено Маастрихтським договором від 7 лютого 1992 p. на базі вже існуючих у Свропі трьох співтовариств, що мали переважно економічний характер.

Теорія і практика функціонування інтеграційних об'єднань привела до визначення трьох категорій договорів, які передбачені правом ЄС. Вони склалися в умовах, коли тільки Співтовариства наділилися статусом юридичної особи і міжнародною правосуб’єктністю.

По-перше, це договори, які укладаються ЄС із третіми державами та (або) міжнародними організаціями. Такого роду договори підписуються від імені $Є \mathrm{C} з$ питань, що відносяться до їх відання.

Другу категорію міжнародних договорів утворюють так звані змішані угоди, які характеризують відносини, що визначаються як сфери відання $\mathrm{CC}$, так і держав-членів. Прикладом такого договору є Угода про асоціацію між Україною та ЄС, яка ратифікована 16 вересня 2014 р. Верховною Радою України та Свропейським парламентом [9].

Третю групу утворюють договори, які укладаються державами-членами, але правові наслідки яких можуть зачіпати безпосередньо ЄС [10, с. 87-89]. 
Висновки. Підсумовуючи викладене, можна зробити висновок, що договір як джерело права визначається як об'єктивоване, формально обов'язкове правило поведінки загального характеру, встановлене за взаємною домовленістю держав, державних утворень, їх органів державної влади у питаннях їхніх взаємовідносин. Існують три основних види таких договорів:

1) договори, які укладаються незалежними державами про утворення нової федеративної держави;

2) внутрішньодержавні договори;

3) міжнародно-правові акти та акти міждержавних організацій.

У світовій практиці державного будівництва зростає роль договору як джерела права. Це зумовлено як внутрішніми факторами кожної країни (рівень демократичності державного устрою, ефективність правотворчої діяльності тощо), так і міжнародним впливом.

ЄС як міжнародне об'єднання конфедеративного типу впливає на більшість аспектів розвитку національних законодавств держав-членів. Вирішення цього завдання суттєво полегшується ступенем правової спільності, притаманної цим законодавствам. У сферах, визнаних спільними, що утворюються інститутами $Є С$, норми слугують усуненню юридичних відмінностей та введенню єдиних, загальних або узгоджених способів законодавчого або договірного регулювання.

\section{Список використаних джерел}

1. Загальна теорія права : підруч. / За заг. ред. М. І. Козюбри. - К. : Ваіте, 2016. - 392 с.

2. Юридична енциклопедія : в 6 т. - К. : «Укр. енцикл.», 1999. - Т. 2. - 744 с.

3. Сборник нормативных актов по советскому государственному праву. - М. : 1984.

4. Конституцзии страны Африки. - т.2. М.: 1966.

5. Чиркин В. Е. Конституционное право зарубежных стран. - М.: Юрист, 1997. - 568 с.

6. Конституции зарубежных государств. Учебное пособие. - М.: Изд.-во БЕК, 1997. - 586 с.

7. Юридична енциклопедія : в 6 т. - К. : «Укр. енцикл.», 1998. - Т.1. - 672 с.

8. Історія Української конституції. - К. : Право, 1997. - 464 с.

9. Офіційний сайт Міністерства закордонних справ України. - http//mfa.gov.ua/un/about-ukraine/europenintegration/ua-eu-assotiation

10. Европейское право. Право Европейского Союза и правовое обеспечение защиты прав человека : учеб. для вузов / Рук. авт. колл. и отв. ред. д. ю. н., проф. Л. М. Энтин - 2-е изд., пересмотр. и доп. - М. : НОРМА, 2005. - 960 с.

\section{Мяловицька Н. А., Златіна Н. Е. Договір як джерело права}

У статті досліджуються поняття джерел права, їх видів, а також розглядається договір як джерело права в регулюванні правових відносин. Визначається поняття договору та їх види. Розглядаються три основних види договорів: договори, які укладаються незалежними державами про утворення нової федеративної держави; внутрішньодержавні договори у федеративних та унітарних державах; міжнародно-правові акти та акти міждержавних організацій.

Зазначається, що у світі загалом зростає роль договору як джерела права. Це обумовлено як внутрішніми факторами кожної країни (рівень демократичності державного устрою, ефективність правотворчої діяльності тощо), так і міжнародним впливом.

Ключові слова: джерела права, договір, держава, конституція, Європейський Союз.

\section{Mialovytska N. A., Zlatina N. E. Contract as a source of law}

The article deals with the concept of sources of law, their types, and also considered the contract as a source of law in the regulation of legal relations. The concept of the contract and its types are determined. There are three main types of treaties: treaties concluded by independent states on the formation of a new federal state; internal treaties in federal and unitary states; international legal acts and acts of intergovernmental organizations.

It is determined that in the international confederal type association, the European Union (EU) has three groups of agreements: treaties concluded by the EU with third countries and (or) international organizations; mixed agreements that define the relations that apply both to the sphere of the EU and to the Member States; contracts concluded by Member States, but the legal consequences of which can be directly affected by the EU.

It is noted that in the whole world the role of the contract as a source of law is growing. This is due both to the internal factors of each country (the level of democracy in the state system, the effectiveness of law-making activity, etc.) and international influence.

Key words: sources of law, treaty, state, constitution, European Union.

DOI: $10.33 .66 .3 / 2524-017 X-2019-10-70-72$ 